УДК 902

DOI: https://doi.org/10.33782/eminak2019.1(25).216

\title{
КЕРАМІЧНІ ЛИВАРНІ ФОРМИ ДЛЯ ВИГОТОВЛЕННЯ АНТИЧНИХ СВІТИЛЬНИКІВ
}

\author{
Ірина Шейко \\ Інститут археології НАН України (Київ, Україна) \\ e-mail: ira.sheiko@gmail.com \\ ORCID: https://orcid.org/0000-0002-2176-8145
}

Розглядаються глиняні ливарні форми античних світильників і матриця для їх виготовлення, що були знайдені в Ольвії під час розкопок попередніх років. Знахідки складають рідкісний тип виробів як для Північно-Причорноморського регіону. Автором здійснено пошук близьких аналогій та уточнено датування згаданих форм. Крім того, актуалізовано питання технології виробництва античних глиняних світильників за допомогою таких форм.

Ключові слова: ливарна форма, світильники, Ольвія, технологія, виробництво

Світильники античного часу привертають увагу дослідників усе частіше, завдяки різноманітним зображенням на щитках, виробів перших віків нашої ери, та декорувальним мотивам на елліністичних освітлювальних приладах. Зацікавлення технологією виробництва означених виробів повсякденного вжитку заслуговує на окреме дослідження.

Спочатку античні світильники виготовляли на гончарному колі, підправляючи плічка та приєднуючи ріжок і ручку окремо. Проте зміна технології виготовлення освітлювальних приладів із біконічною формою тулуба, на відміну від простих відкритих форм, відбулась близько першої половини III ст. до н.е. ${ }^{1}$ Вона полягала у тому, що у спеціально виготовлених ливарних (зазвичай, керамічних) формах відливались або відтискалися обидві частини виробу - верхня та нижня окремо 2 . Доказом цього є знахідки таких форм і світильників, зокрема й в Ольвії.

На теренах Ольвії відомо на сьогодні лише дві форми для виготовлення світильників та одна матриця. 3 появою нового методу виготовлення світильників постала необхідність у створенні форм задля спрощення та пришвидшення цього процесу. Так, з'явилися перші матриці для виготовлення ливарних форм. На них наносили декорувальні мотиви, або зображення, які пізніше матиме форма, i в подальшому й світильник. Для виготовлення світильника, майстрові спочатку доводилося виготовляти з сирої глини, чи штукатурки (?), необхідну матрицю для виробу, потім вирізати необхідні деталі, приміром, ріжок і плічка, а також, у деяких випадках, наносити орнамент для верхньої частини виробу, аби отримати декорований світильник. Після того, як майстер пересвідчився, що усі необхідні деталі зроблено, форма висушувалася та випалювалась ${ }^{3}$. Знахідки подібних гли-

\footnotetext{
${ }^{1}$ Bailey D.M. A Catalogue of the Lamps in the British Museum. Vol. I. Greek, Hellenistic and Early Roman Pottery Lamps. London, 1975. P. 4.

2 Kennedy C.A. The development of the lamp in Palestine // Berytus. Archaeological studies. Vol. XIV (1961-1963). P. 69.

3 Bailey D.M. Op. cit. P. 4.
} 
няних і металевих форм для виготовлення світильників маємо і серед знахідок Віндонісси ${ }^{4}$, афінського Кераміка5, а також деяких міст Боспору Кіммерійського 6.

Коли форма була готова для використання, на неї клали тоненьку матерію, на яку викладали глину для світильника та притискали․ Таким чином, по краях утворювалось багато залишків глини. Далі його залишали висихати. Кожен такий світильник має чіткий шов склейки всередині вмістилища. Дуже часто ми знаходимо світильники, які розкололись по цьому шву, що свідчить про те, що клейкий матеріал був не завжди належної якості, й тому в процесі обпалу виробу він міг розклеїтись ще до його використання8.

Повертаючись до знахідок з Ольвії, усі вироби, що публікуються9 ${ }^{9}$ виготовлено із глини. Перша ливарна форма, наявна у нашій колекції, застосовувалась для виготовлення дворіжкових світильників (рис. 1, 1). Ї̈̈ було знайдено на ділянці НГ в Ольвії, у комплексі, який датується II-I ст. до н.е. ${ }^{10} 3$ приводу подібних дворіжкових світильників Д.В.Журавльов зазначив, що вони вироблялись шляхом приєднання другого ріжка до вже готового одноріжкового світильника елліністичного часу, які зрештою мали спільне вмістилище ${ }^{11}$, проте знахідка в Ольвії форми для його виготовлення свідчить про інше. Факт такої знахідки свідчить про те, що дворіжкові світильники даного типу виготовлялись саме у формі, а не шляхом приєднання другого ріжка. До того ж, знахідки таких світильників на теренах Ольвії дають можливість простежити це завдяки чіткому шву склейки всередині резервуару.

Численні знахідки подібних освітлювальних приладів на теренах Ольвії, а також форми для їх виготовлення, свідчать, що це були лампи вже закритого типу, прикрашені волютами по боках, а на деяких екземплярах також збереглись основи вертикальної ручки. Аналогічні світильники було знайдено на багатьох пам'ятках не лише Причорномор'я (Боспор 12 , Ольвія ${ }^{13}$ ), але й у середземноморських і малоазійських центрах (Пергам, з орнаментом з листя плюща та датою II-I ст. до н.е. ${ }^{14}$; Кнід ${ }^{15}$ ).

\footnotetext{
4 Loeschcke S. Lampen aus Vindonissa. Zürich, 1919. S. 34.

${ }^{5}$ Scheibler I. Griechische Lampen / (Kerameikos. - Bd. 11). Berlin: W. de Gruyter \& Co, 1976. S. 100.

6 Журавлев Д.В., Быковская Н.В., Желтикова А.Л. Светильники второй половины III в. до н.э. - IV в. н.э. Київ: Мистецтво, 2010. (Коллекция светильников; т. II). С. 311-312.

${ }^{7}$ Bailey D.M. Op. cit. P. 5.

8 Байбородин А.И. Из опыта восстановления технологии производства античных керамических светильников // Третьи историко-культурологичные чтения в Николаеве (научно-методический сборник). Николаев, 1999. С. 8.

${ }^{9}$ Висловлюю подяку за надані для роботи матеріали з розкопок Ольвії старшому науковому співробітнику Наукових фондів IA НАНУ Шевченко Тетяні Миколаївні, а також Заступникові завідувача науково-дослідного відділу збереження фондів, Заступнику головного зберігача Національного музею історії України, Пукліній Ользі Олександрівні.

10 Ветштейн Р.И. Местная керамика Ольвии первых векав нашей эры / Ольвия [под ред.: С.Н. Бибикова]. Київ: Наукова думка, 1975. Рис. 3. С. 184.

11 Журавлев Д.В. Позднеэллинистические многорожковые светильники Боспора // Древности Боспора. 2001. Вып. 4. С. 131; Вальдгауер 0.Ф. Античные глиняные светильники. СанктПетербург, 1914. С. 79.

12 Забелина В.С. Античные глиняные светильники из Пантикапея // Сообщения ГМИИ А.С. Пушкина. 1992. Вып. 10. Таб. VII, 5; Журавлев Д.В., Хршановски Л. Коллекция античних светильников Государственного Исторического музея // Вестник древней истории. 2000. Рис. 1, 9; Журавлев Д.В. Позднеэллинистические многорожковые светильники Боспора // Древности Боспора. 2001. Вып. 4. Таб. 1, 1-2.

13 Вальдгауер О.Ф. Указ. раб. Кат. 57; Hǿjte J.M. Lamps // The Lower City of Olbia (Sector NGS) in the $6^{\text {th }}$ Century BC to the $4^{\text {th }}$ Century AD. Aarchus, 2010. Pl. 326, 0-103.

14 Schäfer J. Tonlampen / Hellenistische keramik aus Pergamon. Berlin. 1968. Taf. 63, Q47.
}

Eminak, 2019, 1 (25) 
Також відомі металеві репліки керамічних дворіжкових світильників, зокрема, 3 бронзи, які належать вже до римського часу16. Слід відмітити, що питання про металеві репліки залишається досі дискусійним. Згідно Д.В.Журавльову, саме подібні дворіжкові світильники з металу послугували прототипом для виготовлення глиняних форм ${ }^{17}$. Однак, у такому випадку слід чітко визначити датування як для глиняних, так і для металевих форм освітлювальних приладів цього типу, оскільки останні датуються вже першими століттями нашої ери, на відміну від глиняних екземплярів.

Наступна форма для виготовлення світильників належить до так званих рельєфних виробів (рис. 1, 2). Вона виконана у формі голови Діоніса, з характерними коримбами на голові. Ця форма була раніше опублікована у дослідженні А.С. Русяєвої, та зарахована до числа теракот ${ }^{18}$. Проте, при ближчому ознайомленні із цією формою, вдалося встановити, що у нижній їі частині наявний чітко сформований видовжений ріжок, що дало змогу висловити думку про те, що виріб є нічим іншим, як формою для виготовлення одноріжкових світильників. Крім того, повну аналогію такому світильникові знайдено серед виробів колекції М.Шлоссінгер, який датується I ст. н.е. ${ }^{19}$, але дослідники зазначили, що виріб виготовлено у формі голови Силена. Подібні світильники з Єгипту у формі голови Силена, також датуються у межах I ст. н.е. ${ }^{20}$, а знахідки таких світильників на Боспорі датуються I-II ст. н.е. ${ }^{21}$

Подібні світильники набирають популярності за перших століть нашої ери, а саме за часів Імперії, хоча початок їхнього виробництва припадає саме на елліністичну добу22. Вони виготовлялись у формі голів божеств, тварин, чи частин людського тіла, приміром ніг, і саме через це були часто схожі на теракоти.

Зображення Діоніса не $є$ поодиноким серед глиняних виробів античного часу, адже культ цього божества був привнесений до Північного Причорномор'я та до Ольвії зокрема, ще колоністами. У цьому ключі, цікаво, що у 2011 р. під час дослідження рову римського часу в історичній частині м. Миколаїв, у його заповненні було виявлено фрагменти червонолакового посуду, з яких примітним $\epsilon$ фрагмент рельєфної посудини, на якій зображено аналогічну голову Діоніса ${ }^{23}$. Даний виріб також датується у межах I ст. н.е.

Третій виріб, який розглядається у публікації, $\epsilon$ матрицею для виготовлення одноріжкових світильників (рис. 2, 1), знайденою також як і перший виріб, на ділянці НГ в Ольвії. Такі матриці є доволі рідкісними знахідками. Даний виріб застосовували для виготовлення світильників періоду пізнього еллінізму, а саме І ст. до н.е., продовжуючи на початку I ст. н.е. Аналогій поки що знайти не вдалось.

Проте, у плані виготовлення, світильники з рельєфними орнаментами є також

15 Broneer O. Terracotta Lamps / (Isthmia III). Princeton, N.J., 1977. Pl. 5, 192.

${ }_{16}$ Rosenthal R., Sivan R. Ancient Lamps in the Schloessinger Collection // Qedem. 1978. № 8. Cat. nr. 649-650.

17 Журавлев Д.В., Турова Н.П. Античные глиняные светильники Ялтинского историколитературного музея // Боспорские исследования. 2012. Вып. XXVI. С. 350.

18 Русяева А.С. Религия и культы античной Ольвии. Київ: Наукова думка, 1992. Рис. 29, 1. С. 97.

${ }^{19}$ Rosenthal R., Sivan R. Op. cit. Cat. nr. 594. P. 145.

20 Bailey D.M. Op. cit. Pl. 3, Q 577.EA, 578.

21 Журавлев Д.В., Быковская Н.В., Желтикова А.Л. Указ. раб. С. 265.

22 Rosenthal R., Sivan R. Op. cit. Cat. nr. 594. P. 145.

${ }_{23}$ Смирнов А.И., Ивченко А.В., Козленко Р.А. Исследование оборонительного рва римского времени в г. Николаев // АДУ 2011 р. Київ, 2012. С. 346. 
надзвичайно цікавими. Різноманітні рослинні, геометричні або антропоморфні орнаменти, якими вони оздоблювались, притаманні для виробів саме доби еллінізму. На рівні із нанесенням орнаменту вручну, майстри використовували також спеціальні ливарні форми з уже готовими «штампами» певних орнаментів. Серед відомих вже форм подібні мають переважно ефеське походження 24 . До того ж, простежено таке явище як «зношування» цих відливних форм, що підтверджується нечітким, дещо стертим орнаментальним мотивом на виробі. Крім того, в Ольвії було знайдено п'ять світильників з однаково стертим листковим орнаментом, які мають ідентичні розміри, що свідчить про те, що усі вони могли бути виготовлені з однієї ливарної форми.

Більшість дослідників схиляється до думки про те, що спеціальних майстерень для виготовлення світильників, як окремого виду кераміки, не існувало 25 . Тобто, склад глини, покриття й іноді і декоративні мотиви не відрізняються від тих, які має і решта керамічних виробів. Це означає, що у більшості випадків, наймовірніше, їх виробляли ті ж самі гончарі, які працювали і над виготовленням столового посуду. Однак, якщо говорити про великі центри, які впродовж довгого часу були імпортерами освітлювальних приладів, було б цілком логічним припустити, що такі майстерні все ж могли бути. Принаймні, за свідченнями Арістофана, майстри, які займалися виготовленням винятково глиняних світильників, все ж існували ${ }^{26}$. Проте, Афіни все ж таки являються нетиповим, хоча і досить показовим прикладом.

Крім того, у 2011 р. у Борисфені було виявлено керамічний комплекс VI ст. до н.е., який включав і дві пічки для випалу керамічних виробів. У заповненні однієї з них було знайдено 11 однотипних сіроглиняних одноріжкових світильників ${ }^{27}$. Значення цього відкриття важно переоцінити - це перші відомості про появу місцевого виробництва освітлювальних приладів у Нижньому Побужжі.

Посилаючись на дані Павсанія, Е.О. Левіна припустила, що три робочих майстерні протягом дня (12 год.) могли виготовити більше 200 світильників, оскільки на один екземпляр потрібно було витратити не більше 5 хвилин ${ }^{28}$. По-перше, до таких детальних свідчень античних джерел необхідно ставитись критично, адже число могло бути і перебільшеним. По-друге, ми не маємо контексту, тобто, немає відомостей, про які світильники йшла мова, адже ранні світильники відрізнялись від більш пізніх (принаймні тих, що випускалися за Павсанія) за технологією виробництва і, відповідно, займали різну кількість часу для їхнього виготовлення. Менше з тим, слід вважати таку інформацію дуже загальною.

Таким чином, питання виготовлення світильників античного часу, завдяки зна-

\footnotetext{
${ }^{24}$ Giuliani A. Lampenmatrizen hellenistischer Zeit aus ephesischer Produktion im Rijksmuseum van Oudheden, Leiden // Jahreshefte des Österreichischen Archäologischen Institutes in Wien. Band 74. 2005. P. 73-83.

25 Broneer O. Op. cit. P. 5; Howland R.H. Greek lamps and their survivals (The Athenian Agora. - Vol. IV). Princeton, 1958. P. 3-4; Bailey D.M. Op. cit. P. 3.

26 Журавлев Д.В., Завойкин А.А. Светильники из святилища элевсинских богинь «Береговой 4» // Боспорский феномен: проблемы хронологии и матировки памятников. Материалы международной научной конференции. 2004. Ч. 1. С. 119.

27 Крутилов В.В., Смирнов А.И., Бондаренко Д.В. Керамический производственный комплекс середины VI в. до н.э. на Березанском античном поселении // Боспорские чтения XIII. Боспор Киммерийский и варварский мир в период античности и средневековья. Проблемы урбанизации. Керчь, 2012. C. 233-237.

28 Левина Э.А. Античные светильники Одесского археологического музея (I-VI вв. н.э.). Одесса, 1992. C. 5.
} 
хідкам спеціальних ливарних керамічних форм і матриці в Ольвії, стає більш зрозумілим. Згадані форми за складом глини належать до місцевих ольвійських виробів, що дає змогу припускати, що в Ольвії могло існувати місцеве виробництво освітлювальних приладів.

\section{REFERENCES}

Baiborodin, A.I. (1999). Iz opyta vosstanovlenia tehnologii proizvodstva antichnykh keramicheskikh svetilnikov [From the Experience of Reconstruction of the Ancient Clay Lamps Production Technology]. Tretie istoriko-kulturnye chtenia v Nikolaieve (nauchno-metodicheskii sbornik), 7-10 [in Russian].

Bailey, D.M. (1975). A Catalogue of the Lamps in the British Museum. Vol. I: Greek, Hellenistic and Early Roman Pottery Lamps. London [in English].

Broneer, 0. (1977). Terracotta Lamps. (Isthmia III). Princeton, N.J. [in English].

Giuliani, A. (2005). Lampenmatrizen hellenistischer Zeit aus ephesischer Produktion im Rijksmuseum van Oudheden, Leiden. In Jahreshefte des Österreichischen Archäologischen Institutes in Wien. Band 74 (pp. 73-83) [in German].

Hǿjte, J.M. (2010). Lamps. In The Lower City of Olbia (Sector NGS) in the $6^{\text {th }}$ Century BC to the $4^{\text {th }}$ Century $A D$. (pp. 423-437). Aarhus: University of Aarhus [in English].

Howland, R.H. (1958). Greek lamps and their survivals. The Athenian Agora. Vol. IV. Princeton [in English].

Kennedy, C.A. (1961-1963). The Development of the Lamp in Palestine. Berytus. Archaeological studies, XIV, 67-115 [in English].

Krutilov, V.V., Smirnov, A.I. \& Bondarenko, D.V. (2012). Keramicheskii proizvodstvennyi kompleks srediny VIv. do n.e. na Berezanskom antichnom poselenii [Ceramic Production Complex of the Middle of the VIc. BC at the Berezan Ancient Settlement]. Bosporskie chtenia, 13, 233-237 [in Russian].

Levina, E.A. (1992) Antichnye svetilniki Odesskogo arkheologicheskogo museia (I-VI vv. n.e.) [Ancient Lamps from the Odessa Archaeological Museum (I-VI c. AD)]. Odessa [in Russian].

Loeschcke, S. (1919). Lampen aus Vindonissa. Zürich [in German].

Rosenthal, R. \& Sivan, R. (1978). Ancient Lamps in the Schloessinger Collection. Qedem, 8, 1-179 [in English].

Rusiaeva, A.S. (1992). Religia i kulty antichnoi Olvii [Religion and Cults of Ancient Olbia]. Kyiv: Naukova dumka [in Russian].

Schäfer, J. (1968). Tonlampen. In Hellenistische keramik aus Pergamon, (pp. 119-153). Berlin [in German].

Scheibler, I. (1976). Griechische Lampen. Kerameikos. Bd. 11. Berlin: W. de Gruyter\&Co [in German].

Smirnov, A.I., Ivchenko, A.V., Kozlenko, R.A. (2012). Issledovanie oboronitelnogo rva rimskogo vremeni v g. Nikolaev [The Research of the Defensive Moat of the Roman Time in Mykolaiv]. Arkheologichni doslidzhennia v Ukraini 2011, 346-347 [in Russian].

Valdhauer, O.F. (1914). Antichnye hlinianye svetilniki [Ancient Clay Lamps]. Sankt-Peterburg [in Russian].

Vetshtein, R.I. (1975). Mestnaia keramika iz Ovvii pervykh vekov nashei ery [Local Pottery from Olbia of the First Centuries AD]. In Olvia (pp. 164-197). Kyiv: Naukova dumka [in Russian].

Zabelina, V.S. (1992). Antichnye glinianye svetilniki iz Pantikapeia [Ancient Clay Lamps from Panticapaeum]. Soobshchenia Gosudarstvennogo Muzeia Istorii Iskesstv imeni A.S. Pushkina, 10, 298328 [in Russian].

Zhuravlev, D.V. (2001). Pozdneellinisticheskie mnogorozhkovye svetilniki Bospora [Late Hellenistic Multi-nozzled Lamps of the Bosporan Kingdom]. Drevnosti Bospora, 4, 131-149 [in Russian].

Zhuravlev, D.V., Bykovskaia, N.V., Zheltikova, A.L. (2010). Svetilniki vtoroi poloviny III v. do n.e. - IV v. n.e. [Lamps of the Second Half of the III c. BC - IV c. AD]. Kyiv: Mystetstvo [in Russian].

Zhuravlev, D.V. \& Zavoikin, A.A. (2004). Svetilniki iz sviatilishcha elevsinskikh bogin «Beregovoi 4» [Lamps from the Elevsinian Goddesses Temple «Beregovoi 4»]. Bosporskii fenomen, 2, 191-199 [in Russian].

Zhuravlev, D.V. \& Turova, N.P. (2012). Antichnye glinianye svetilniki Yaltinskogo istoriko-literaturnogo museia [Ancient Clay Lamps from the Yalta Historical and Literature Museum]. Bosporskie issledovania, 26, 335-400 [in Russian].

Zhurzvlev, D.V. \& Hrshanovski, L. (2000). Kollektsyia antichnykh svetilnikov Gosudarstvennogo 
Istoricheskogo museia [The Collection of Ancient Lamps from the State Historical Museum]. Vestnik Drevnei Istorii, 3, 159-166 [in Russian].

\section{Iryna Sheiko}

(Institute of Archaeology of the National Academy of Science of Ukraine, Kyiv, Ukraine)

ORCID: https://orcid.org/0000-0002-2176-8145

\section{Ceramic Moulds for Making Ancient Lamps}

The author publishes clay moulds of ancient lamps and archetype for their production, which were found in Olbia during excavations of previous years. Findings are a rare type of production items for both the Northern Black Sea region and the ancient Mediterranean world as a whole.

The search for close analogies has been performed and the dating of the mentioned moulds has been defined more precisely. Lamps that could have been made using similar moulds have analogies not only among the cities of the Northern Black Sea region but also among other centers of the ancient world. Besides, in Roman times, such lighting devices started also to be made of metal, in particular, we know bronze replicas of the mentioned moulds, which make it possible to assume that the ceramic production items of these types were of fairly high popularity and inspired the craftsmen to produce their metal versions as well. The assumption about the local origin of these moulds and archetype is made. In addition, the question of the ancient clay lamps production technology with the help of such moulds is raised.

The author mentions the dynamics of the lamps production process from the pre-Roman times, until the fundamental change in the technology that took place in the $3^{\text {rd }}$ century BC. The issue and some thoughts about the local Olbia craft production of the ancient-time lighting devices are presented after finding the moulds, and the complex of the stove from the ancient settlement on the island Berezan, where early ancient gray clay lamps were found. One of the moulds for making lamps was previously mistakenly published in the section of ancient terracottas, and after the search for analogies in the newest archaeological sources, the author has managed to specify this information.

Keywords: mould, lamps, Olbia, technology, production 


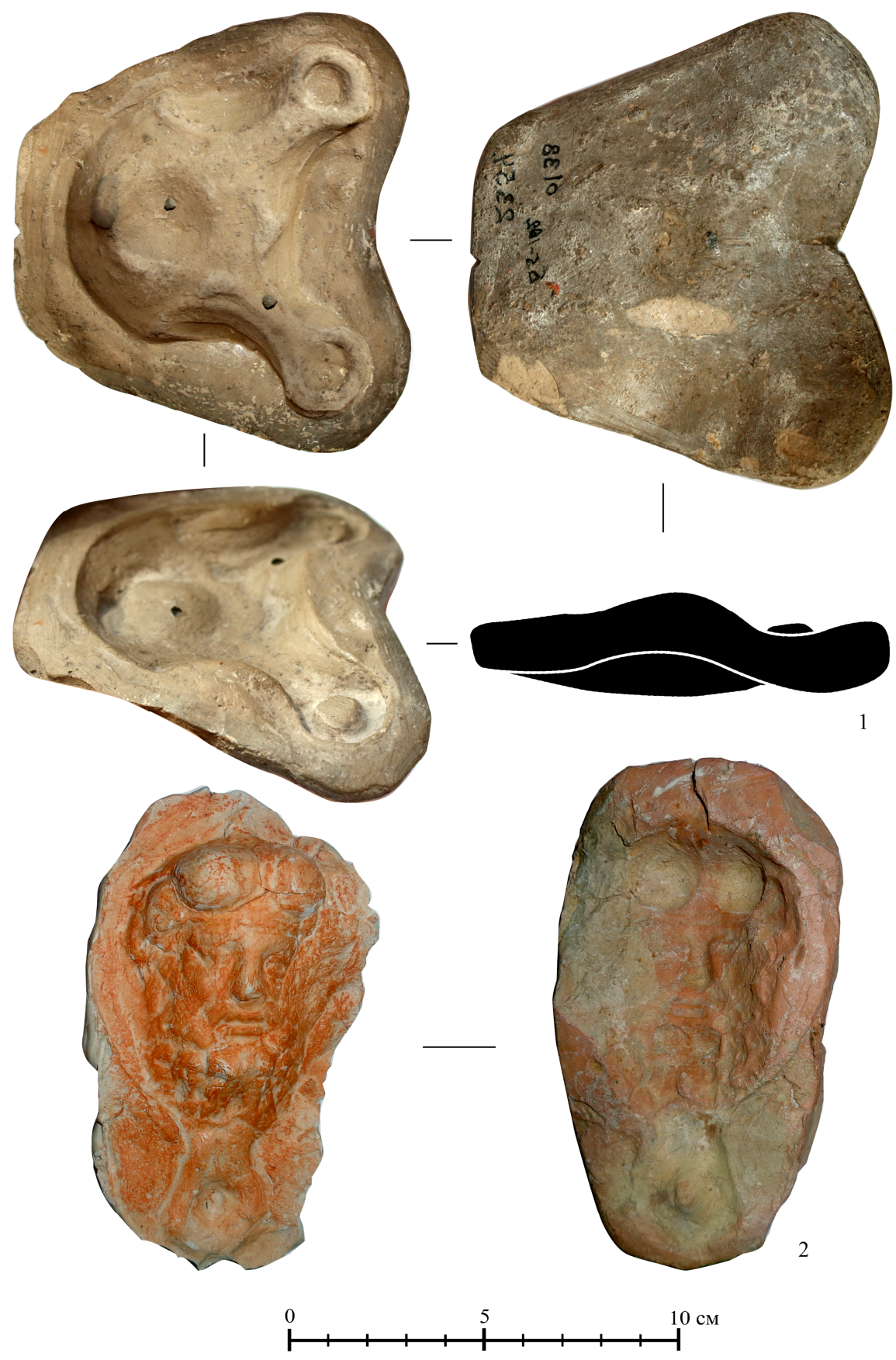

Рис. 1. Ливарны форми для виготовлення дворіжкових світильників 


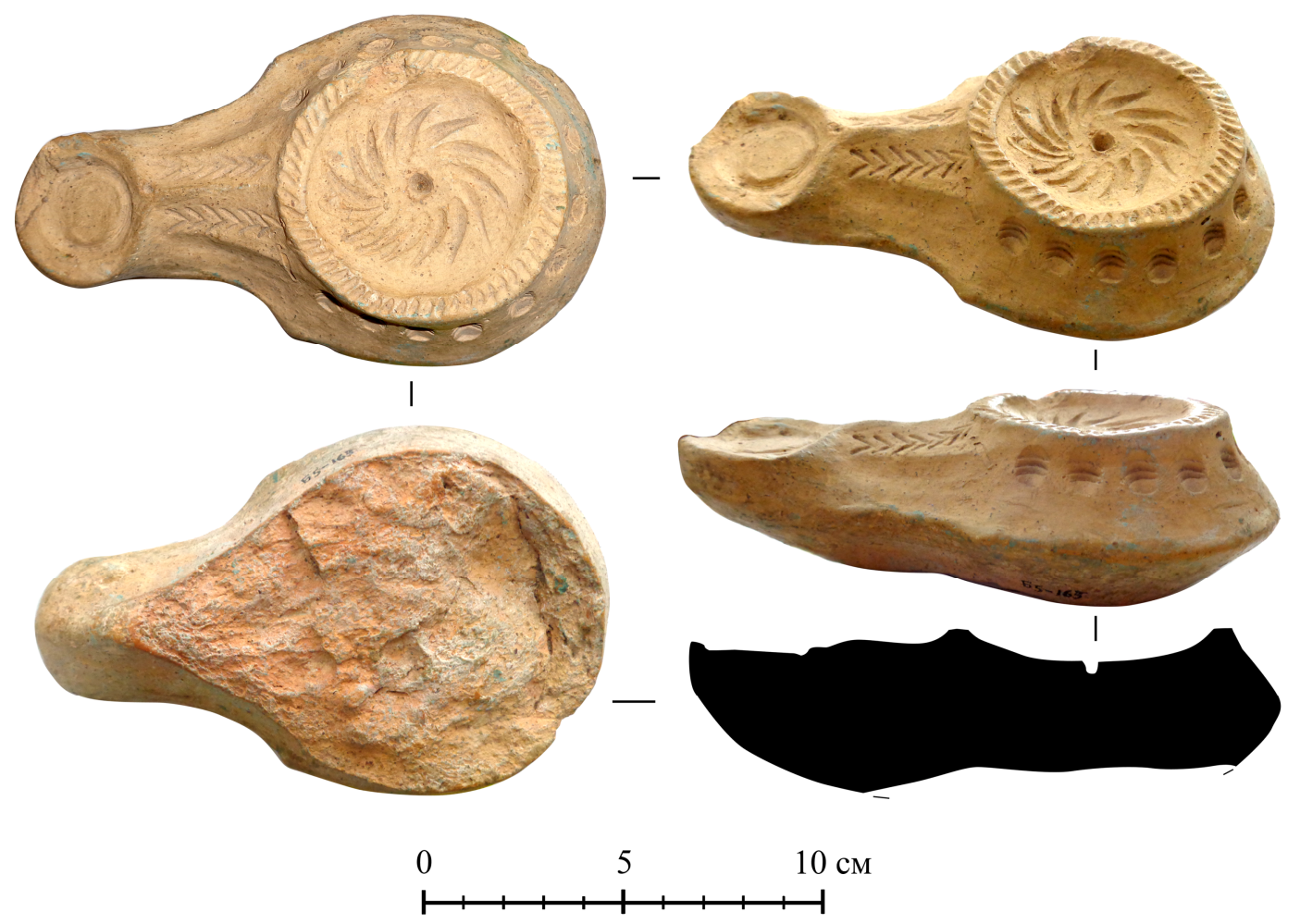

Рис. 2. Матриця для виготовлення одноріжкових світильників 